\title{
Human lactoferrin but not lysozyme neutralizes HSV-I and inhibits HSV-I replication and cell-to-cell spread
} Hannamari Välimaa*1,2,3,4, Jorma Tenovuo ${ }^{1,5}$, Matti Waris ${ }^{2}$ and Veijo Hukkanen ${ }^{2,6}$

\begin{abstract}
Address: ${ }^{1}$ Institute of Dentistry, University of Turku, Turku, Finland, ${ }^{2}$ Department of Virology, University of Turku, Turku, Finland, ${ }^{3} \mathrm{Haartman}$ Institute, Department of Virology, University of Helsinki, Helsinki, Finland, ${ }^{4}$ Helsinki University Central Hospital Laboratory, Helsinki, Finland, ${ }^{5}$ Department of Oral Diseases, Turku University Central Hospital, Turku, Finland and ${ }^{6}$ Department of Microbiology, University of Oulu, Oulu, Finland

Email: Hannamari Välimaa* - hannamari.valimaa@helsinki.fi; Jorma Tenovuo - jorma.tenovuo@utu.fi; Matti Waris - matti.waris@utu.fi; Veijo Hukkanen - veijo.hukkanen@oulu.fi

* Corresponding author
\end{abstract}

Published: 12 May 2009

Virology Journal 2009, 6:53 doi:10.1186/1743-422X-6-53

This article is available from: http://www.virologyj.com/content/6/I/53

(C) 2009 Välimaa et al; licensee BioMed Central Ltd.

This is an Open Access article distributed under the terms of the Creative Commons Attribution License (http://creativecommons.org/licenses/by/2.0), which permits unrestricted use, distribution, and reproduction in any medium, provided the original work is properly cited.
Received: 16 December 2008

Accepted: 12 May 2009

\begin{abstract}
The frequent oral shedding of herpes simplex virus type I (HSV-I) in the absence of clinical disease suggests that symptomatic HSV-I recurrences may be inhibited by the mucosal environment. Indeed, saliva has been shown to contain substances with anti-HSV activity. In the current study, we investigated the anti-HSV-I activity of human lactoferrin (hLf) and lysozyme (hLz), two highly cationic polypeptides of the mucosal innate defence system.

HLf blocked HSV-I infection at multiple steps of the viral replication cycle, whereas lysozyme displayed no anti-HSV-I activity. Preincubation of HSV-I virions and presence of hLf during or after viral absorption period or for the entire HSV-I infection cycle inhibited HSV-I infection by reducing both the plaque count and plaque size in a dose- and virus strain-dependent manner. Cellto-cell spread of wild-type HSV-I and the strain gC-39, deleted of glycoprotein C, was dramatically reduced, but the cell-to-cell spread of HSV-I Rid I, harboring a mutated gD and thus unable to react with the cellular HVEM receptor, remained unchanged. This suggests that the inhibition of cell-tocell spread is mediated by effects on gD or its cellular counterparts.

Our results show that the cationic nature is not a major determinant in the anti-HSV action of mucosal innate cationic polypeptides, since whereas hLf inhibited HSV-I infection efficiently, hLz had no HSV-I inhibiting activity. Our results show that in addition to inhibiting the adsorption and post-attachment events of HSV-I infection, hLf is also able to neutralize HSV-I and that the inhibition of cell-to-cell spread involves viral gD. These results suggest that $L f$ may have a significant role in the modulation of HSV-I infection in the oral cavity as well as in the genital mucosa, the major sites of HSV-I infection.
\end{abstract}

\section{Findings}

Oral mucosa is a common site of primary herpes simplex virus type 1 (HSV-1) infection. After a primary infection in the oral region, HSV-1 establishes latency in the trigeminal ganglion. Subsequent reactivation of HSV-1 typically results in asymptomatic shedding of virus into saliva, but 
only rarely in detectable intraoral lesions. Instead, extraoral manifestations are frequent and affect 20-40\% of the HSV-seropositive population [1]. Thus the intraoral environment may inhibit replication of HSV-1.

Lactoferrin (Lf) and lysozyme (Lz) are highly cationic polypeptides with broad antimicrobial properties, abundant in saliva, tears and cervicovaginal mucosal fluid. The major inhibitory mechanism of Lf on HSV infection has been suggested to occur by competitive binding of Lf to negatively charged cell surface glycosaminoglycans (GAGs) [2-4]. Furthermore, we have observed human Lf (hLf) to inhibit post-attachment events in the HSV-1 replication including entry and cell-to-cell spread [5]. This finding has been confirmed with both bovine and human Lf $[6,7]$. Lactoferrin has also been suggested to affect the HSV reactivation phenotype in the oral region [8].

The most characterized antimicrobial property of $\mathrm{Lz}$ is its antibacterial muramidase activity, although some enzyme-independent functions have been reported [9]. Observations on anti-HSV activity of Lz are contradictory $[10,11]$, but likely involve both enzymatic and cationic properties of this enzyme [10].

In this study, we compared the anti-HSV activity of human lactoferrin and lysozyme, and the roles of viral glycoproteins gC and gD therein. We infected Vero cell monolayers with HSV-1 in the presence or absence of human milk-derived non-iron-saturated lactoferrin (apoLf; L-0520, Sigma), iron-saturated lactoferrin (satLf; L-3770, Sigma) or lysozyme (hLz; L-6394, Sigma). Virus strains used were the wild-type (wt) HSV-1 strain KOS, and the KOS-derived mutants Rid 1 and gC-39. Rid 1 has a single amino acid substitution at position 27 of gD, a viral glycoprotein essential for viral entry, that results in the inability of this virus to use HVEM as an entry mediator [12]. gC-39 lacks glycoprotein $\mathrm{C}$, the major viral envelope glycoprotein mediating initial attachment of HSV-1 to cell surface GAGs [13].

First, confluent Vero cell monolayers on 24-well plates were infected with 100 or 200 plaque-forming units (pfu) of HSV-1 KOS, Rid1 or gC-39. For the infection studies, fetal calf serum (FCS) concentration of MEM culture medium with antibiotics was reduced from $10 \%$ to $1 \%$ and medium was supplemented with $0-500 \mu \mathrm{g} / \mathrm{ml}$ of apoLf or satLf, or $0-200 \mu \mathrm{g} / \mathrm{ml}$ of $\mathrm{hLz}$ at various time points of infection (Figures 1, 2, 3, 4). Cultures with medium without hLf and hLz served as negative controls. Quadruplicate cultures were fixed with methanol 20 hours post-infection (h.p.i.), and infected cells were identified by immunoperoxidase staining (IPS) of viral proteins with HRP-labelled polyclonal antibodies against HSV-1 (P0175, DakoCytomation, Denmark, A/S) (modified from [14]). The number of plaques and plaque size was determined by light microscopy.

Second, 50 pfu of HSV-1 KOS, Rid1, or gC-39 was adsorbed to Vero cell monolayers in 12-well plates for $2 \mathrm{~h}$ at $37^{\circ} \mathrm{C}$. The inoculum was removed and fresh MEM added, containing 1\% FCS, antibiotics and $0.1 \%$ human gammaglobulin supplemented with $0-500 \mu \mathrm{g} / \mathrm{ml}$ of apoLf or satLf, or $0-200 \mu \mathrm{g} / \mathrm{ml}$ of hLz. After five days,

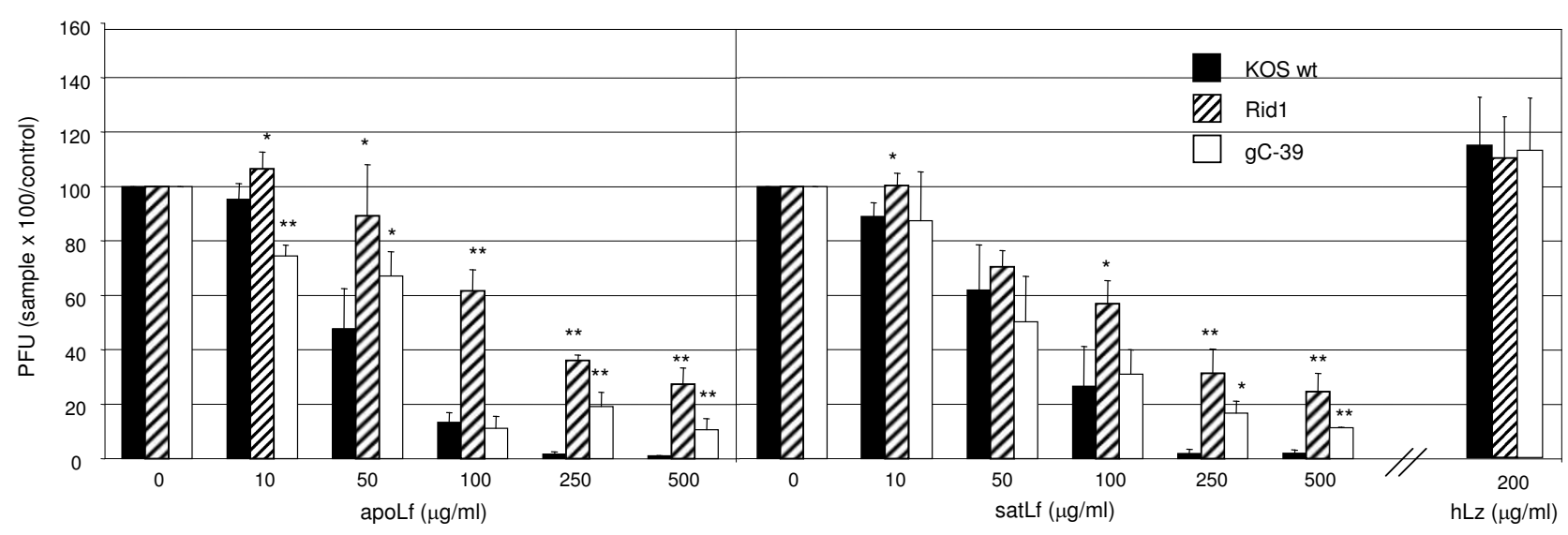

Figure I

Lactoferrin but not lysozyme inhibited efficiently HSV-I infection of Vero cells. Replication of wt HSV-I and mutant viruses gC-39 and Ridl in Vero cells with human non-iron-saturated Lf (apoLf), iron-saturated Lf (satLf) or lysozyme (hLz) present throughout the entire replication cycle. Lactoferrin and lysozyme were added to cell cultures $24 \mathrm{~h}$ prior to infection. The relative amount of viral plaques, in comparison to untreated cultures, is shown. Error bars represent standard deviations of three separate experiments. Statistical significance in the level of inhibition: $*=p<0.05$, $* *=p<0.005$, mutant viruses compared to wt KOS. Only results with the highest concentration of hLz used are shown. 


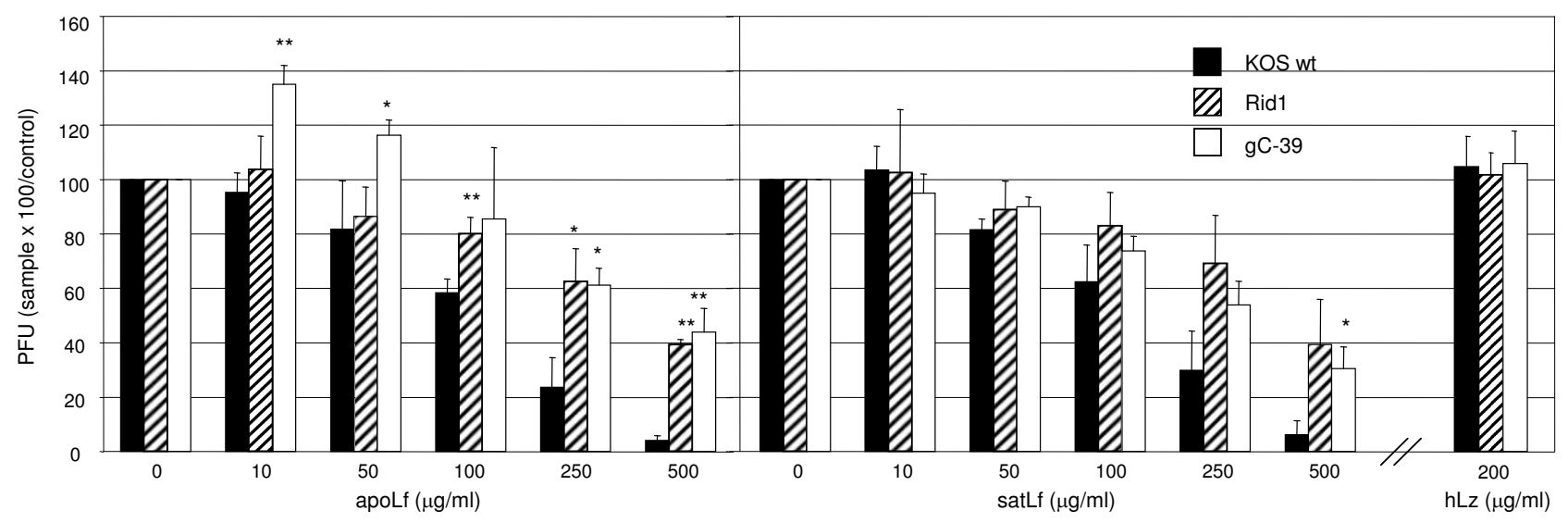

Figure 2

Lactoferrin but not lysozyme neutralized HSV-I. Wt HSV-I and mutant viruses gC-39 and Rid I were incubated for 30 min at $37^{\circ} \mathrm{C}$ with different concentrations of human non-iron-saturated Lf (apoLf), iron-saturated Lf (satLf) or lysozyme (hLz) prior to inoculation of Vero cell cultures. Preincubated virus/hLf mixtures were diluted I:I0 upon addition to the cell culture so that the inoculum contained $\mathrm{I}-50 \mu \mathrm{g} / \mathrm{ml}$ of $\mathrm{hLf}$. Therefore the observed inhibition could not have resulted from the hLf effect on the cells. The relative amount of viral plaques, in comparison to untreated cultures, is shown. Error bars represent standard deviations of three separate experiments. Statistical significance in the level of inhibition: $*=p<0.05$, $* *=p<0.005$, mutant viruses compared to wt KOS. Only results with the highest concentration of hLz used are shown.

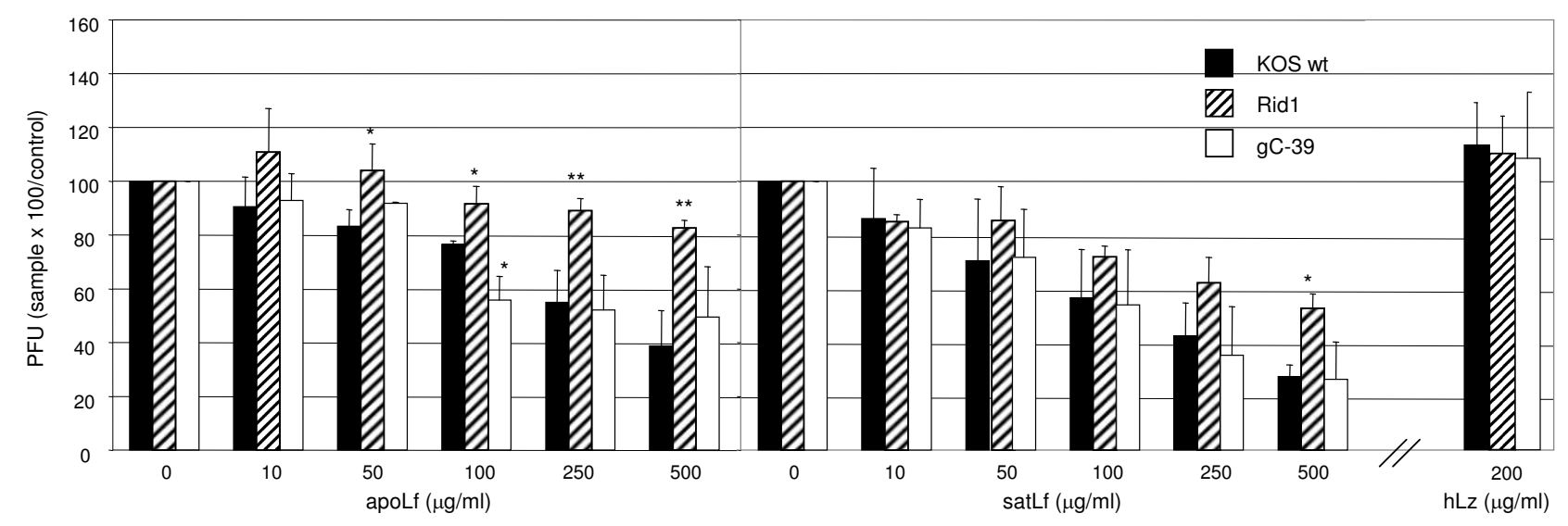

Figure 3

Pretreatment of cell cultures with lactoferrin but not lysozyme inhibited HSV-I infection. Vero cell cultures were pretreated with human non-iron-saturated Lf (apoLf), iron-saturated Lf (satLf) or lysozyme (hLz) for $24 \mathrm{~h}$ prior to inoculation. To exclude lactoferrin and lysozyme effect on HSV-I virion, these supplements were removed from the media by washing before inoculation of cultures with wt HSV-I and mutant viruses gC-39 and Rid I. The relative amount of viral plaques, in comparison to untreated cultures, is shown. Error bars represent standard deviations of three separate experiments. Statistical significance in the level of inhibition: $*=p<0.05$, ${ }^{* *}=p<0.005$, mutant viruses compared to wt KOS. Only results with the highest concentration of hLz used are shown. 


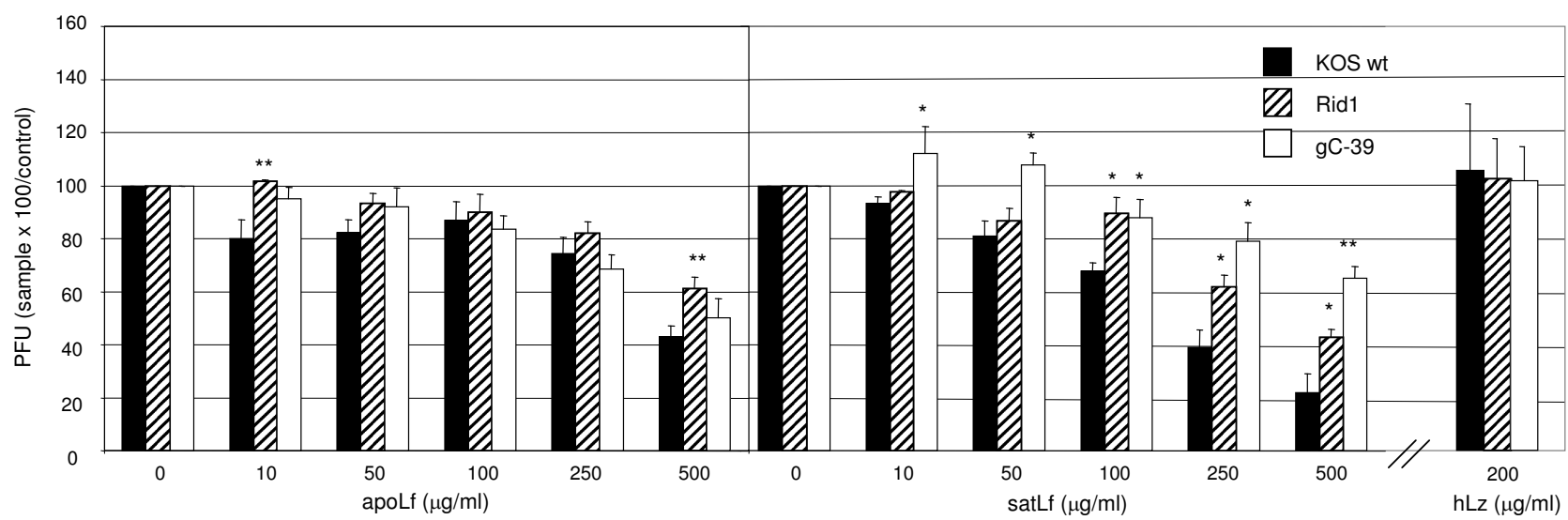

\section{Figure 4}

Lactoferrin has inhibitory activity against HSV-I infection also after viral adsorption. To study the lactoferrin effect on post-attachment events, wt HSV-I and mutant viruses gC-39 and Rid I were adsorbed to cells at $4^{\circ} \mathrm{C}$, cultures were washed and human non-iron-saturated Lf (apoLf), iron-saturated Lf (satLf) or lysozyme (hLz) was added. The relative amount of viral plaques, in comparison to untreated cultures, is shown. Error bars represent standard deviations of three separate experiments. Statistical significance in the level of inhibition: $*=p<0.05$, $* *=p<0.005$, mutant viruses compared to wt KOS. Only results with the highest concentration of hLz used are shown.

plaques formed by viruses were visualized by crystal violet staining. Data were analysed by Student's two-tailed paired t-test, and p-values less than 0.05 were considered significant.

We found human lactoferrin (hLf) to interfere with the progression of HSV-1 infection at multiple steps of the viral replication cycle, whereas human lysozyme displayed no anti-HSV-1 activity. The degree of hLf iron-saturation played little role in HSV-1 inhibition.

In the series of inhibition assays, cells were first maintained in hLf containing medium for $24 \mathrm{~h}$ before viral inoculation and subsequently through the whole replication cycle (Figure 1). Already at a hLf concentration of 50$100 \mu \mathrm{g} / \mathrm{ml}, \mathrm{HSV}-1$ replication was dramatically inhibited independent of the degree of Lf iron-saturation. Both of the mutant viruses, Rid1 and gC-39, were significantly more resistant to hLf-mediated inhibition, indicating a role for both $\mathrm{gC}$ and $\mathrm{gD}$ in the inhibition of viral replication.

A series of further experiments was carried out investigating hLf effect on the virion, the absorption and postabsorption events in the replication cycle and cell-to-cell spread. We found hLf to neutralize unbound wt HSV-1 with an $\mathrm{IC}_{50}$ of $100-250 \mu \mathrm{g} / \mathrm{ml}$ of hLf (Figure 2 ). HSV-1 mutants, gC-39 and Rid1, were significantly more resistant to hLf-mediated neutralization, suggesting that neutralization is mediated by effects of hLf on gC and gD or their cellular counterparts. Moreover, preincubation of
gC-39 with apoLf unexpectedly enhanced infectivity in low concentrations. This suggests that hLf binding to virion compensates for gC and facilitates formation of contacts between virion bound hLf and cell surface Lf receptors, as has been earlier also suggested to occur between bovine Lf and $\mathrm{gC}^{-39}$ [4]. Instead, bLf has been found unable to neutralize wt HSV-1 $[3,6]$, although it has been shown to bind to wt HSV-1 [2].

Wt HSV-1 and gC-39 were equally sensitive ( IC $_{50} 250 \mu \mathrm{g} /$ $\mathrm{ml}$ ) to hLf pretreatment of cells (Figure 3), suggesting that this inhibition involves interactions participated by both $\mathrm{gC}$ and $\mathrm{gB}$, the other major glycoprotein mediating attachment [15]. Cell surface GAGs have been shown to bind Lf [4] and Lf anti-HSV-1 activity to decrease in the absence of heparan sulphate [3] or viral gC when Lf was added to cultures simultaneously with the virus [4]. These findings strongly suggest a major role for inhibition of initial attachment of both $\mathrm{gB}$ and $\mathrm{gC}$ to GAGs in the anti-HSV action of Lf. In our study, pretreatment of cells inhibited also Rid 1 in higher hLf concentrations, suggesting that hLf inhibition is not restricted only to HSV attachment to the cell surface, but may also modulate gD-mediated viral entry.

The sensitivity of post-attachment steps to hLf-mediated inhibition was confirmed by the observed anti-HSV-1 activity of hLf added to cultures after viral adsorption (Figure 4). Of the studied viral strains, wt HSV-1 was the most sensitive with $\mathrm{IC}_{50}$ of $250-500 \mu \mathrm{g} / \mathrm{ml}$ of hLf. Iron-saturated form of hLf was slightly more effective. Rid1 infec- 


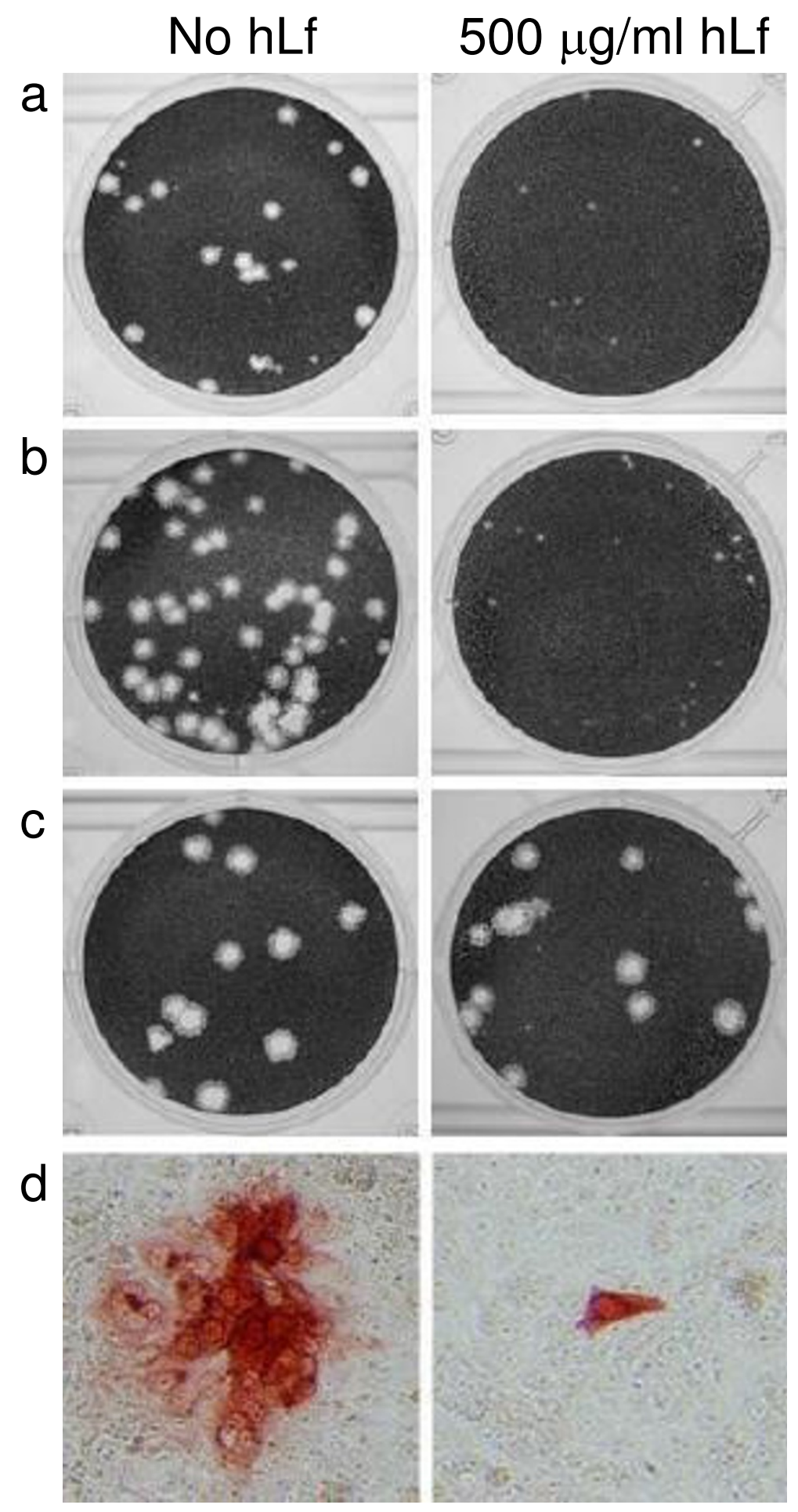

\section{Figure 5}

Lactoferrin inhibition of HSV-I cell-to-cell spread is mediated by gD. HSV-I KOS (a, d), gC-39 (b) and Rid I (c) infection of Vero cells in the absence or presence of $500 \mu \mathrm{g} / \mathrm{ml}$ of human lactoferrin. Plaques formed by the infecting virus were visualized by crystal violet staining after 5 days of culture in the presence of human immunoglobulin (a-c) or by immunoperoxidase staining with polyclonal anti-HSV-I antibody after $20 \mathrm{~h}$ of culture (d). Lactoferrin dramatically impaired the cell-to-cell spread of HSV-I KOS and gC-39, but not of RidI. 
tivity decreased $40-60 \%$ at a hLf concentration of $500 \mu \mathrm{g} /$ $\mathrm{ml}$. Earlier, bLf has been shown not to affect differentially on the entry of wt HSV- 1 and Rid 1 strains in a $\beta$-galactosidase assay [3]. Therefore, the observed gD-associated post-attachment inhibition in our study may yield from Lf interference with intracellular events in the replication cycle or with the synthetized progeny viral components or virions. Previously, both hLf [5] and bLf [6] have been shown to reduce HSV-1 plaque number if added immediately after viral adsorption or $1 \mathrm{~h}$ after viral entry. This inhibition has been suggested to result from Lf binding to viral components intracellularly [6]. The N-terminal region of Lf has been shown to carry a nuclear localization signal [16] and to be able to translocate to the nucleus of the cell [17]. The efficiency and mechanisms of Lf binding and intake seem to be cell type-specific and to involve various receptors $[3,7,17-19]$. Therefore certain intracellular antiviral effects of Lf may differ between cell types.

HLf was furthermore found to efficiently inhibit HSV-1 cell-to-cell spread as observed by crystal violet staining five days post-infection and by IPS 20 h.p.i. (Figure 5.). This observation corroborates with previous observations [5-7]. In the current study, the inhibition was highly virus strain-dependent. Cell-to-cell spread of wt and gC-39 viruses, but not of Rid1, was dramatically impaired at hLf concentration of $500 \mu \mathrm{g} / \mathrm{ml}$ independently of the degree of hLf iron-saturation (Figure 5). Some inhibition was observed already at a concentration of $250 \mu \mathrm{g} / \mathrm{ml}$, but not in lower concentrations (data not shown). Cell-to-cell spread is known to involve primarily $\mathrm{gB}$ and $\mathrm{gE} / \mathrm{gI}$ and also gD in certain cell types $[20,21]$, but not gC directly [22-24]. The susceptibility of gC-negative HSV-1 strain, gC-39, to inhibition of cell-to-cell spread may result from hLf interference with $\mathrm{gB}$ binding to heparan sulphate at cell junctions [24]. More importantly, the fact that the plaque-size of Rid1, with a modified gD, was not affected by hLf, suggests that the observed inhibition is dependent on $\mathrm{gD}$ or its cellular counterparts. Earlier, inhibition of HSV-1 cell-to-cell spread by lactoferricin, a peptide generated from Lf by pepsin cleavage, has been shown to involve chondroitin sulphate [7]. It is possible, that in addition to inhibiting cell-to-cell spread of HSV-1, hLf localized to the cell surface may also modulate the infectivity of the released progeny virus.

In conclusion, we found hLf to interfere with the progression of HSV-1 infection at multiple steps of the viral replication cycle and with HSV-1 cell-to-cell spread in a doseand virus strain-dependent manner. Our studies show for the first time that in addition to inhibiting the adsorption and post-attachments steps of HSV-1 infection, hLf is also able to neutralize HSV-1 and that the inhibition of cell-tocell spread is at least partly dependent on $\mathrm{gD}$ or its cellular counterparts. The degree of hLf iron-saturation played lit- tle role in the inhibition. HLz displayed no anti-HSV-1 activity, suggesting that cationic property alone has no significant role in the anti-HSV activity of a polypeptide of the mucosal innate defence system.

\section{Competing interests}

The authors declare that they have no competing interests.

\section{Authors' contributions}

HV participated in the design of the study, carried out the experiments and drafted the manuscript. $\mathrm{VH}, \mathrm{MW}$ and JT have participated in the design of the study and helped drafting the manuscript. All authors read and approved the final manuscript.

\section{Acknowledgements}

We are grateful to Prof. Patricia Spear and Dr. William Goins for providing mutant viruses gC-39 and Ridl as well as the corresponding wild-type viruses for our studies. This study was supported by Emil and Blida Maunula Foundation at University of Turku and Turku Dental Society. Prof. Veijo

Hukkanen is the recipient of the grant \#I 18366 of the Academy of Finland.

\section{References}

I. Wheeler CE Jr: The herpes simplex problem. J Am Acad Dermatol 1988, 18:163-168.

2. Marchetti M, Longhi C, Conte MP, Pisani S, Valenti P, Seganti L: Lactoferrin inhibits herpes simplex virus type I adsorption to vero cells. Antiviral Res 1996, 29:22I-23I.

3. Andersen JH, Jenssen H, Sandvik K, Gutteberg TJ: Anti-HSV activity of lactoferrin and lactoferricin is dependent on the presence of heparan sulphate at the cell surface. J Med Virol 2004, 74:262-27I.

4. Marchetti M, Trybala E, Superti F, Johansson M, Bergstrom T: Inhibition of herpes simplex virus infection by lactoferrin is dependent on interference with the virus binding to glycosaminoglycans. Virology 2004, 3 I 8:405-4I 3.

5. Välimaa H: Innate and adaptive immunity in orolabial herpes simplex virus infection. PhD Thesis 2006:D7II [https://oa.doria.fi/ bitstream $/$ handle//0024/360I2/D7II.pdf?sequence $=$ I] . University of Turku

6. Ammendolia MG, Marchetti M, Superti F: Bovine lactoferrin prevents the entry and intercellular spread of herpes simplex virus type I in green monkey kidney cells. Antiviral Res 2007, 76:252-262.

7. Jenssen H, Sandvik K, Andersen JH, Hancock RE, Gutteberg TJ: Inhibition of HSV cell-to-cell spread by lactoferrin and lactoferricin. Antiviral Res 2008, 79:192-198.

8. Valimaa H, Waris M, Hukkanen V, Blankenvoorde MF, Nieuw Amerongen AV, Tenovuo J: Salivary defense factors in herpes simplex virus infection. J Dent Res 2002, 81:416-42I.

9. Laible NJ, Germaine GR: Bactericidal activity of human lysozyme, muramidase-inactive lysozyme, and cationic polypeptides against streptococcus sanguis and streptococcus faecalis: Inhibition by chitin oligosaccharides. Infect Immun 1985, 48:720-728.

10. Cisani G, Varaldo PE, Pompei R, Valisena S, Satta G: Cell fusion induced by herpes simplex is inhibited by hen egg-white lysozyme. Microbios 1989, 59:73-83.

II. Oevermann A, Engels M, Thomas U, Pellegrini A: The antiviral activity of naturally occurring proteins and their peptide fragments after chemical modification. Antiviral Res 2003, 59:23-33.

12. Dean HJ, Terhune SS, Shieh MT, Susmarski N, Spear PG: Single amino acid substitutions in gD of herpes simplex virus I confer resistance to gD-mediated interference and cause celltype-dependent alterations in infectivity. Virology 1994, 199:67-80.

13. Holland TC, Homa FL, Marlin SD, Levine M, Glorioso J: Herpes simplex virus type I glycoprotein C-negative mutants exhibit 
multiple phenotypes, including secretion of truncated glycoproteins. J Virol 1984, 52:566-574.

14. Ziegler T, Waris M, Rautiainen M, Arstila P: Herpes simplex virus detection by macroscopic reading after overnight incubation and immunoperoxidase staining. J Clin Microbiol 1988, 26:2013-2017.

15. Herold BC, Visalli RJ, Susmarski N, Brandt CR, Spear PG: Glycoprotein $C$-independent binding of herpes simplex virus to cells requires cell surface heparan sulphate and glycoprotein B. J Gen Virol 1994, 75(Pt 6): I I I - I 222.

16. Penco S, Scarfi S, Giovine M, Damonte G, Millo E, Villaggio B, Passalacqua M, Pozzolini M, Garre C, Benatti U: Identification of an import signal for, and the nuclear localization of, human lactoferrin. Biotechnol Appl Biochem 200I, 34:15I-159.

17. Legrand D, Vigie K, Said EA, Elass E, Masson M, Slomianny MC, Carpentier M, Briand JP, Mazurier J, Hovanessian AG: Surface nucleolin participates in both the binding and endocytosis of lactoferrin in target cells. Eur J Biochem 2004, 271:303-317.

18. Ji ZS, Mahley RW: Lactoferrin binding to heparan sulfate proteoglycans and the LDL receptor-related protein. further evidence supporting the importance of direct binding of remnant lipoproteins to HSPG. Arterioscler Thromb 1994, 1 4:2025-203i.

19. Suzuki YA, Shin K, Lonnerdal B: Molecular cloning and functional expression of a human intestinal lactoferrin receptor. Biochemistry 200I, 40: I577I-15779.

20. Ligas MW, Johnson DC: A herpes simplex virus mutant in which glycoprotein $D$ sequences are replaced by beta-galactosidase sequences binds to but is unable to penetrate into cells. J Virol 1988, 62: 1486-1494.

21. Huber MT, Wisner TW, Hegde NR, Goldsmith KA, Rauch DA, Roller RJ, Krummenacher C, Eisenberg RJ, Cohen GH, Johnson DC: Herpes simplex virus with highly reduced $\mathrm{gD}$ levels can efficiently enter and spread between human keratinocytes. Virol 200I, 75: 10309-103I8.

22. Dingwell KS, Brunetti CR, Hendricks RL, Tang Q, Tang M, Rainbow AJ, Johnson DC: Herpes simplex virus glycoproteins $E$ and I facilitate cell-to-cell spread in vivo and across junctions of cultured cells. J Virol 1994, 68:834-845.

23. Dingwell KS, Johnson DC: The herpes simplex virus gE-gI complex facilitates cell-to-cell spread and binds to components of cell junctions. J Virol 1998, 72:8933-8942.

24. Laquerre S, Argnani R, Anderson DB, Zucchini S, Manservigi R, Glorioso JC: Heparan sulfate proteoglycan binding by herpes simplex virus type I glycoproteins B and $\mathbf{C}$, which differ in their contributions to virus attachment, penetration, and cell-tocell spread. J Virol 1998, 72:6119-6130.
Publish with Biomed Central and every scientist can read your work free of charge

"BioMed Central will be the most significant development for disseminating the results of biomedical research in our lifetime. "

Sir Paul Nurse, Cancer Research UK

Your research papers will be:

- available free of charge to the entire biomedical community

- peer reviewed and published immediately upon acceptance

- cited in PubMed and archived on PubMed Central

- yours - you keep the copyright
BioMedcentral 